\title{
Patronage in Rural Punjab: Evidence from a New Household Survey Dataset
}

\author{
Azam Chaudhry $^{*}$ and Kate Vyborny ${ }^{* * * *}$
}

\begin{abstract}
The intervention of local elites is often cited as an impediment to policy implementation in many developing countries. In this paper, we present initial results from an original primary household dataset from eight tehsils of rural Punjab, Pakistan. We examine descriptive statistics on patron-client interaction and correlations between household characteristics and that relationship. The study raises some key findings. First, households report connections with a range of officials; they interact most heavily with local officials, but a large number of households also report interacting with their provincial and national politicians. Second, many households report receiving active assistance both from local officials and from provincial and national politicians in accessing certain state services, in particular in applying for national identity cards. Third, households report links with many patrons outside their own biraderi or clan. Fourth, vulnerable households, such as landless and female-headed households, appear less likely to interact with and less likely to receive assistance from patrons, suggesting that patronage activity could increase the inequality of outcomes. Fifth, better-off households appear more likely to assist patrons in a range of areas. Finally, local officials and politicians had tended to recommend candidates in the last election, and rural households were strongly convinced that their vote was not secret from their patrons or officials. This is possibly consistent with patronage-based politics and bloc voting.
\end{abstract}

Keywords: Patron, client, rural, Pakistan.

JEL classification: P16, D7.

\footnotetext{
* Associate Professor, Lahore School of Economics, Pakistan.

** Doctoral Candidate, St. Antony's College, University of Oxford.

*** We are grateful to Marcel Fafchamps, Ali Cheema, Matthew Nelson, and Steve Lyon, for suggestions concerning the development of questions for the PERI survey. We would like to thank Haseeb Ashraf, Amber Nasir, Misha Saleem, Zunnia Timarzee, and Zehra Gardezi for excellent research assistance. We particularly appreciate the collaboration of the Punjab Bureau of Statistics, the Centre for the Study of African Economies at Oxford (particularly the help of Rose Page, Richard Payne, and Gail Wilkins) and the Lahore School of Economics (particularly the support of Naved Hamid, Masooma Habib, and Shahid Amjad Chaudhry). We gratefully acknowledge the British Academy International Partnerships Initiative and the Rhodes Trust for supporting our collaboration.
} 


\section{Introduction}

The activity of local elites, such as powerful landlords, is frequently cited as a major challenge to social and development interventions in rural areas of many developing countries. Local elites are sometimes said to block efforts at rural development or social assistance because their power is threatened by others helping "their" villagers. Alternatively, they are described as diverting the benefits of social or government programs to those in their families or social networks (elite capture). They may also play a role in wider distribution while reaping the personal or political benefits of acting as a benefactor in securing goods and services from donors or the central government on behalf of their clients. Rural Pakistan is thought to be a prime example of such relationships: indeed, it is even frequently described as a "feudal" society. Analytical work in political economy substantiates these concerns: Cheema, Mohmand, and Patnam (2009) have demonstrated the importance of local elites in this context, and the persistence of their power to resolve disputes and mediate between citizens and the state from the colonial period to the present.

However, donor and government programs often fail to take this apparently very significant feature of rural societies into account when designing interventions. For example, Mansuri and Rao (2004), in their critical review of community-driven development initiatives, point out that the question of how the "community" is represented in decision making is critical and underscrutinized. In general, the decisions taken are highly subject to local power dynamics that might completely escape the funder's attention. The relationships between local elites and other community members may, however, play a major role not only in these types of decentralized programs but also in the de facto distribution of more centralized state programs through patronage networks of interaction between political actors and local elites.

Conversely, and potentially harder to observe, patrons may play a role in wider distribution while reaping the personal or political benefits of presenting themselves as benefactors providing goods and services. Thus, interventions can affect local power dynamics in ways that donors and central governments might not be sufficiently aware. Labonne (2012) finds that local elected officials received the political credit for a World Bank conditional cash transfer program, benefiting significantly at the ballot box in areas where it was implemented, even though they were not, in fact, responsible for its implementation. 
A better understanding of the mechanisms of these relationships and the circumstances under which they are strengthened or weakened is essential to ensuring that governments and donors design and implement effective programs to benefit the poor. To that end, we aim to shed light on the following research question: how do patron-client relationships affect which households gain access to state-provided goods and services?

Our working definition of patron-client relationships is any "vertical" social connection, i.e., between parties with unequal resources or power, in which flexible assistance or services may be provided that are not specified contractually.

In this paper, we present preliminary results from a newly collected household dataset from Punjab, Pakistan, which can be used to help answer this question. We first review the literature to demonstrate why microdata on political patronage are needed and how these data fit in with the existing work in this area. We then describe the dataset and its collection, and present descriptive statistics and a simple analysis of the results. After this, we focus on a few key issues: (i) Do patrons help relatively privileged or underprivileged households? (ii) How do clients gain access to patrons? (iii) What is the role of biraderi (kinship) in these patron-client relationships? (iv) What is the relationship between patronage and electoral activity? Finally, we present plans for more extensive analytical research.

\section{Literature Review}

There is a well-developed body of literature on interlinking contracts in rural areas of developing countries. These contracts, in which two or more factors of production are traded within a single relationship, may provide a partial solution to market failures. For example, landlords who frequently provide credit to their tenants are in a better position to determine creditworthiness (solving information asymmetry) and enforce repayment (addressing moral hazard). In many regions, including South Asia, much more far-reaching relationships have been observed in which laborers may be "tied" to a given landlord and may provide many services (not clearly specified in advance) in exchange for broad patronage and protection, including, for example, risk smoothing or protection from threats.

Scott (1972) discusses how patron-client relationships characterized by social or economic imbalances lead to exchanges between the patron and client (which are solidified by personal interaction). Platteau (1995a) 
typologizes such relationships and, from this framework, develops theoretical predictions about the important factors determining whether these types of comprehensive relationships will persist or break down. Among these, he identifies the opportunity costs of the laborers (e.g., market labor opportunities) and the landlords (e.g., returns to higher education or entering business in the city); the labor-intensiveness of existing or newly introduced production technology; and the ability of the patrons to use social (or state) enforcement mechanisms.

Shami (2010b), who uses mixed qualitative and quantitative methods to study a small sample of villages in Hafizabad, Pakistan, finds a significant difference in landlord-tenant relationships in villages near a recently constructed motorway. The residents of more accessible villages report less resistance and even significant assistance from their landlords in providing public goods such as improved drainage. She argues that tenants' outside option to pursue market-based work (provided by access to the motorway) improved their bargaining power and changed their landlords' behavior. In the interlocking contracts language, the latter were prompted to provide better services as part of their contract.

Another related stream of literature examines the political economy of resource distribution, in particular, "pork-barrel" politics. This aims explicitly to understand the behavior of elected officials in bringing state resources to their constituencies, in particular to a level that results in inefficiently high local public goods provision. Legislators forego more useful national or regional projects in favor of bringing home something tangible that local voters will see and give them credit for. ${ }^{1}$ For example, Keefer and Khemani (2009) study the Constituency Development Fund in Indian states and examine circumstances under which legislators put more effort into "pork." The authors find this occurs where party affiliation is stronger.

Related to this is the literature on "clientelism," which is defined by Brusco, Nazareno, and Stokes (2002) as a situation in which voters trade votes for immediate payoffs as opposed to forward-looking choices over programs and backward evaluation of previous performance. Robinson and Verdier (2001) discuss how high levels of income inequality and

\footnotetext{
1 Analyzing these questions is challenging because of the difficulty of distinguishing between useful and effective constituency representation and rent seeking. One can test empirically whether politically powerful areas receive more public goods and thus answer a distributional question, but to say anything about efficiency-i.e., whether excessive local public goods are being deliveredrequires that one analyze the marginal returns of such projects, which may be difficult.
} 
hierarchal social relations tend to lead to clientelist politics. Wantchekon (2002) finds that clientelist platforms have a significant impact on voting behavior with the strongest effect for local and incumbent candidates.

This political economy literature is highly relevant when analyzing patron-client relationships because the structure of local patrons delivering their community's votes to a politician in return for local services or personal favors may well involve some of this delivery of local public goods. However, this literature tends to focus on local public goods rather than private goods and benefits. It also focuses on how electoral dynamics, and not social networks, affect decisions about the distribution of resources. We focus on the distribution of individual-level benefits and how this is influenced by both electoral dynamics and the access households have to different types of patrons through social networks.

A separate body of literature examines elite capture of programs and benefits, and asks whether powerful individuals influence the design and delivery of local public or semi-public goods, or direct the delivery of private goods and benefits, to gain more of the benefits for themselves or those in their social networks. A newer strand of this literature specifically examines who benefits from elite capture and distribution, in terms of the social networks of patrons and office holders. Caeyers and Dercon (2008) use household survey data from Ethiopia to study the relationship between local officials whom a household reports knowing and receipts of food aid. They find that those who are socially connected to elected officials are more likely to be awarded the program and receive benefits in excess of the official levels. Fafchamps and Labonne (2012) use familial relationships, observed through naming traditions, to test whether those related to elected officials are more likely to receive public health insurance or enter public employment, finding a significant effect on the latter.

Endogeneity is a major challenge for many possible empirical approaches here. In particular, endogenous reporting of relationships (e.g., a more helpful relative in office may be more likely to be reported than a less helpful one) is a problem. Distinguishing information flows from direct favoritism is also challenging. Fafchamps and Labonne (2012) use household survey data from before a recent election to test the relatives of current elected officials against those of future officials (i.e., those who were elected after the survey took place) to rule out systematic differences in the families of office holders causing the effect. However, the differential spread of information, rather than direct favoritism, could still potentially drive these results. 
However, this body of literature has an important and policyrelevant gap we hope to help address: there is limited quantitative work on the interaction between social networks, local sources of power such as land, and the mediation and diversion of state-provided goods and services. To what extent is access to state services included as part of the package of services that a landlord/patron offers his tenants/clients? To what extent does the ability to mediate access to state resources affect a patron's bargaining power? What is the relationship between landlords and elected or state officials and how do each of these groups mediate access to state services? Additional microdata can help develop an understanding of the mechanisms of elite capture and intermediation of state goods, of who benefits, and under what circumstances patrons will be stronger and weaker in distributing resources.

There is rich material in the qualitative literature to develop the questions we have raised here-even if we restrict our attention to qualitative work on Pakistan. For example, Martin (in press), who has studied areas of Punjab and Swat (Khyber Pakhtunkhwa) through ethnographic fieldwork, describes how a generation of landlords increases their wealth levels, move to the city to pursue business interests, and are eventually overturned as patrons by a newer group.

This is consistent with the outside option for landlords as a key variable in Platteau's (1995a) theoretical framework, but adds a dimension describing the change over time: who fills the vacuum, if anyone, when the relationship changes from a patronage-based one to an absentee landlord relationship? Khan (in Khan \& Jomo, 2000) develops a qualitative theory on patronage in which he cites examples from Pakistan and other countries in Asia to demonstrate differing outcomes depending on whether patronage systems work within or outside the state bureaucracy (this raises the question of how these systems develop in different ways).

\section{Description of Survey}

The unique dataset we have used to analyze patron-client relationships was collected as part of the Privatization in Education Research Initiative (PERI) survey conducted in April 2011. The survey was based on the Punjab government's Multiple Indicator Cluster Survey (MICS), which is a household survey conducted at the district level for Punjab. The PERI survey revisited a random sample of the 2007/08 MICS survey households, creating a panel. 
The original MICS household survey was conducted in 2003/04. It was followed up by the next round conducted in 2007/08 by the Punjab government in collaboration with UNICEF, the objective being to gather information on critical development indicators for women and children in Punjab and relate this information to targets set by the Millennium Development Goals. Covering 35 districts in Punjab (with both rural and urban households in the sample), the survey gathered detailed householdlevel information as well as detailed health-related information on women and children under five in each household.

The PERI survey revisited 1,024 of the MICS households in 64 rural villages in eight tehsils across northern, southern, and central Punjab in 2011. Given the survey's research objectives, it focused on rural Punjab (excluding western Punjab, which had been largely affected by floods). The survey's household-level questions were identical to those asked in the MICS questionnaire, though the MICS modules that focused on women and children under five were not included. Besides household-level information, the survey also collected information on the household's relationship with a range of government and nongovernment officials and landlords. ${ }^{2}$ Note that the survey questionnaire and enumerators never referred to these individuals as "patrons" but simply asked about household members' relationships and interactions with individuals in particular offices or roles. The survey also asked questions about the assistance provided by these "patrons" over a range of dimensions, and the assistance provided by the household to the patrons.

We now present descriptive statistics and a basic analysis of the household-level data gathered on these patron-client relationships.

\section{Descriptive Statistics}

Every household in the survey named at least one contact from the categorized list of potential patrons that enumerators used to elicit responses. As Table 1 shows, a significant number of respondents named the local numberdar (26 percent) or imam masjid (21 percent) as their patron, followed by national assembly members or candidates (15 percent) and provincial assembly members or candidates (9 percent). Interestingly, members and candidates of the national and provincial assemblies were named almost as often as the local numberdar.

2 Since the survey had several purposes, it included new modules (different from the MICS) on education quality and school choice, women's assets and decision-making, households' experience of natural disasters, and financial transfers and insurance. 
Table 1: Patrons named as contacts by survey respondents

\begin{tabular}{|c|c|c|c|c|c|c|c|c|c|c|c|}
\hline Landlords & $\begin{array}{l}\text { No. of } \\
\text { HHs with } \\
\text { contact }\end{array}$ & Politicians & $\begin{array}{l}\text { No. of } \\
\text { HHs with } \\
\text { contact }\end{array}$ & $\begin{array}{c}\text { Local } \\
\text { officials }\end{array}$ & $\begin{array}{l}\text { No. of } \\
\text { HHs with } \\
\text { contact }\end{array}$ & $\begin{array}{c}\text { Higher-level } \\
\text { officials (tehsil } \\
\text { to national) }\end{array}$ & $\begin{array}{l}\text { No. of } \\
\text { HHs with } \\
\text { contact }\end{array}$ & $\begin{array}{c}\text { NGO and } \\
\text { religious } \\
\text { leaders }\end{array}$ & $\begin{array}{l}\text { No. of } \\
\text { HHs with } \\
\text { contact } \\
\end{array}$ & Other & $\begin{array}{l}\text { No. of } \\
\text { HHs with } \\
\text { contact }\end{array}$ \\
\hline $\begin{array}{c}\text { Local } \\
\text { landlord } \\
\text { owning }>50 \\
\text { acres }\end{array}$ & 50 & $\begin{array}{c}\text { National } \\
\text { assembly } \\
\text { member }\end{array}$ & 167 & Patwari & 63 & DCO & 1 & $\begin{array}{c}\text { NGO staff/ } \\
\text { staff of trust or } \\
\text { organization }\end{array}$ & 7 & $\begin{array}{c}\text { Trader/ } \\
\text { arthi }\end{array}$ & 20 \\
\hline $\begin{array}{c}\text { Local } \\
\text { landlord } \\
\text { owning }<50 \\
\text { acres }\end{array}$ & 23 & $\begin{array}{l}\text { National } \\
\text { assembly } \\
\text { candidate }\end{array}$ & 79 & Numberdar & 393 & $\begin{array}{l}\text { District nazim/ } \\
\text { naib nazim }\end{array}$ & 27 & Imam masjid & 324 & $\begin{array}{c}\text { Sahookar/ } \\
\text { money trader }\end{array}$ & 1 \\
\hline \multirow[t]{6}{*}{ Farmer a } & 32 & $\begin{array}{l}\text { Provincial } \\
\text { assembly } \\
\text { member }\end{array}$ & 115 & $\begin{array}{l}\text { Member of } \\
\text { zakat } \\
\text { committee }\end{array}$ & 19 & $\begin{array}{l}\text { Tehsil nazim/ } \\
\text { naib nazim }\end{array}$ & 40 & $\begin{array}{c}\text { Spiritual } \\
\text { guide/pir/ } \\
\text { gaddi nasheen }\end{array}$ & 18 & Chairman a & 2 \\
\hline & & $\begin{array}{l}\text { Provincial } \\
\text { assembly } \\
\text { candidate }\end{array}$ & 26 & $\begin{array}{l}\text { Member of } \\
\text { jirgal } \\
\text { punchyiat }\end{array}$ & 20 & $\begin{array}{c}\text { Police } \\
\text { personnel }\end{array}$ & 14 & & & 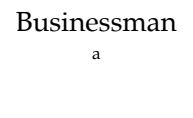 & 3 \\
\hline & & $\begin{array}{l}\text { Political } \\
\text { worker a }\end{array}$ & 2 & $\begin{array}{l}\text { Union } \\
\text { council } \\
\text { member }\end{array}$ & 39 & $\begin{array}{c}\text { Army } \\
\text { personnel }\end{array}$ & 9 & & & $\underset{\text { a }}{\text { Schoolteacher }}$ & 1 \\
\hline & & & & $\underset{\mathrm{a}}{\text { Union nazim }}$ & 1 & $\begin{array}{c}\text { Judge or } \\
\text { sessions judge }\end{array}$ & 8 & Priest a & 1 & Trader a & 1 \\
\hline & & & & $\begin{array}{l}\text { Mohallah } \\
\text { member a }\end{array}$ & 1 & $\begin{array}{l}\text { Other } \\
\text { provincial } \\
\text { govt. rep. }\end{array}$ & 1 & & & $\begin{array}{c}\text { Social worker } \\
\text { a }\end{array}$ & 1 \\
\hline & & & & Councilor a & 1 & $\begin{array}{c}\text { Judicial worker } \\
\text { a }\end{array}$ & 4 & & & & \\
\hline
\end{tabular}

Note: $\mathrm{a}=$ respondent-named categories were not in the prompted list but were named by respondents when asked whether they knew any other person in each category listed. 


\section{Glossary}

Imam masjid = male prayer leader in a mosque.

Jirga (occasionally jargah) $=$ Tribal assembly of elders that takes decisions by consensus. It is similar to that of a town meeting in the US or a regional assembly in the UK, where important regional matters are addressed among the people of the area.

Mohallah (or town) committee = Civil society initiative that includes town residents and police officers. Its role is to maintain functioning relationships between the various ethnicities and between the residents and the police.

Nazim = Coordinator of a city or town in Pakistan; the Urdu title of the chief elected official of a local government in Pakistan, such as a district, tehsil, union council, or village council.

Numberdar = Liaison person between the village and administrative officials who keeps village records and assists in tax collection. Larger villages have more than one numberdar.

Patwari (variously known as talatti, karnam, adhikari, etc.) = Village accountant; an administrative government position found in rural parts of the Indian Subcontinent.

Union or village council = Elected local government body consisting of 21 councilors, and headed by a nazim (equivalent to a mayor) and a naib nazim (deputy). Union councils are the fifth tier of government in Pakistan and the area represented by a union council usually comprises a large village and the surrounding areas, often including nearby small villages. The term can also be used for localities that are a part of cities. Zakat = Annual tax on Muslims to aid the poor in the Muslim community. It is collected through a decentralized and voluntary system, under which zakat committees are established to help collect and distribute zakat funds. 
Table 2 presents the results of a descriptive regression to identify correlates of a household's contact with a patron. "Contact" is defined as the household reporting that they know a person who holds a particular position, broken down by patron type. Wealthier households, i.e., those who own their own dwelling/agricultural land, are more likely to know many types of patrons, while female-headed households, who are typically more vulnerable, are less likely to know some of them. The patterns also differ by region, with households in northern Punjab about 20 percent more likely to report knowing politicians (as compared to central Punjab, the reference category), but far less likely to report knowing religious leaders (likely driven in part by the prominence of pirs, or hereditary religious leaders, in central and southern Punjab). 
Table 2: Correlates of household link with patrons

\begin{tabular}{|c|c|c|c|c|c|c|c|c|}
\hline & (1) & (2) & (3) & (4) & (5) & (6) & (7) & (8) \\
\hline & \multicolumn{8}{|c|}{ LPM: Household reports knowing one or more of the following individuals: } \\
\hline & $\begin{array}{c}\text { Landlords } \\
\text { owning > } \\
50 \text { acres }\end{array}$ & Politicians & $\begin{array}{c}\text { Local } \\
\text { officials }\end{array}$ & $\begin{array}{c}\text { Tehsil, } \\
\text { district, or } \\
\text { provincial } \\
\text { officials }\end{array}$ & $\begin{array}{l}\text { Police or } \\
\text { army } \\
\text { personnel }\end{array}$ & $\begin{array}{c}\text { Religious } \\
\text { leaders }\end{array}$ & $\begin{array}{l}\text { Market } \\
\text { players }\end{array}$ & NGOs \\
\hline \multicolumn{9}{|l|}{ VARIABLES } \\
\hline \multirow[t]{2}{*}{ Owns dwelling } & $0.0368^{* *}$ & $0.0893^{* *}$ & 0.139 & 0.0393 & $0.0136^{* *}$ & $0.189^{* *}$ & -0.0196 & 0.000804 \\
\hline & $(0.0167)$ & $(0.0297)$ & $(0.0886)$ & $(0.0245)$ & $(0.00548)$ & $(0.0750)$ & $(0.0120)$ & $(0.00564)$ \\
\hline \multirow[t]{2}{*}{ Owns agricultural land } & 0.0243 & $0.134^{* * *}$ & $0.0837^{* *}$ & $0.0326^{*}$ & 0.0145 & 0.0329 & $0.0243^{* *}$ & 0.00553 \\
\hline & $(0.0225)$ & $(0.0432)$ & $(0.0378)$ & $(0.0171)$ & $(0.0132)$ & $(0.0238)$ & $(0.0104)$ & $(0.00685)$ \\
\hline \multirow[t]{2}{*}{ Female-headed } & $-0.0709^{* * *}$ & 0.0498 & 0.00194 & 0.0584 & -0.0101 & $-0.0999^{* * *}$ & 0.0153 & $-0.00671^{*}$ \\
\hline & $(0.0223)$ & $(0.0732)$ & $(0.0570)$ & $(0.0331)$ & $(0.0191)$ & $(0.0269)$ & $(0.0138)$ & $(0.00340)$ \\
\hline \multirow[t]{2}{*}{ Northern Punjab } & -0.0489 & $0.216^{* * *}$ & -0.133 & $-0.0751^{* *}$ & -0.00192 & $-0.259^{*}$ & 0.0417 & 0.00992 \\
\hline & $(0.0305)$ & $(0.0660)$ & $(0.148)$ & $(0.0304)$ & $(0.0121)$ & $(0.142)$ & $(0.0331)$ & $(0.00583)$ \\
\hline \multirow[t]{2}{*}{ Southern Punjab } & 0.0180 & 0.0458 & 0.0238 & $-0.0844^{* *}$ & -0.0197 & -0.0351 & 0.00300 & -0.00149 \\
\hline & $(0.0476)$ & $(0.0816)$ & $(0.0989)$ & $(0.0303)$ & $(0.0115)$ & $(0.0767)$ & $(0.00629)$ & $(0.00510)$ \\
\hline \multirow[t]{2}{*}{ Constant } & $0.0393^{*}$ & 0.0427 & $0.336^{* * *}$ & $0.0690^{* *}$ & 0.0120 & $0.248^{* * *}$ & 0.0124 & 0.00257 \\
\hline & $(0.0185)$ & $(0.0437)$ & $(0.0922)$ & $(0.0269)$ & $(0.00865)$ & $(0.0809)$ & $(0.0118)$ & $(0.00378)$ \\
\hline Observations & 1,012 & 1,012 & 1,012 & 1,012 & 1,012 & 1,012 & 1,012 & 1,012 \\
\hline R-squared & 0.022 & 0.081 & 0.038 & 0.042 & 0.010 & 0.085 & 0.027 & 0.005 \\
\hline
\end{tabular}

Notes: Cluster-robust standard errors (clustered at national assembly constituency level) in parentheses; ${ }^{* * *}=p<0.01,^{* *}=p<0.05,{ }^{*}=p<0.1$. 


\section{Access to Patrons}

We now explore more detailed data on the level of access that households have to various patrons. The ease with which clients can contact patrons may determine the extent of assistance the client receives from the patron. However, that access itself is likely to reflect differences in the social, political, and economic status of the client and the patron. In addition, reciprocity in the relationship may drive the frequency of contact: if a landlord needs laborers to work on his land regularly, then he may meet clients far more frequently than a politician who only needs to obtain votes from clients every few years.

Measuring the level of interaction (as discussed by Scott, 1972) is a feature of the social networks literature, and incorporating it distinguishes our approach to patronage from traditional political economy approaches. We also asked survey respondents about more concrete measures of access, such as whether the household has access to the patron, more reliable than hypothetical questions, including:

- How often the household members meet the patron

- How the household could get in touch with the patron if needed (whether they have a telephone number for the patron or a number for someone who can reach him, or if they could visit the patron's house or office without an appointment, etc.)

Figures 1-4 show the breakdown of the frequency of interaction and means of accessing each category of patron. The results for politicians and other common categories are shown separately to highlight the very different patterns these follow. Although many households reported knowing a politician, most of them interacted with him or her infrequently. About 40 percent of households indicated that they could meet the politician in person at his or her home or office; most of the rest said they could not initiate contact at all (for example, they could only meet him or her if he or she visited their village). For all other categories of patron, even those other than locally-based officials, such as district-level officials and police and army officers, households reported much more frequent meetings and the ability to contact or visit without an appointment. 
Figure 1: Frequency of meeting patrons: Politicians

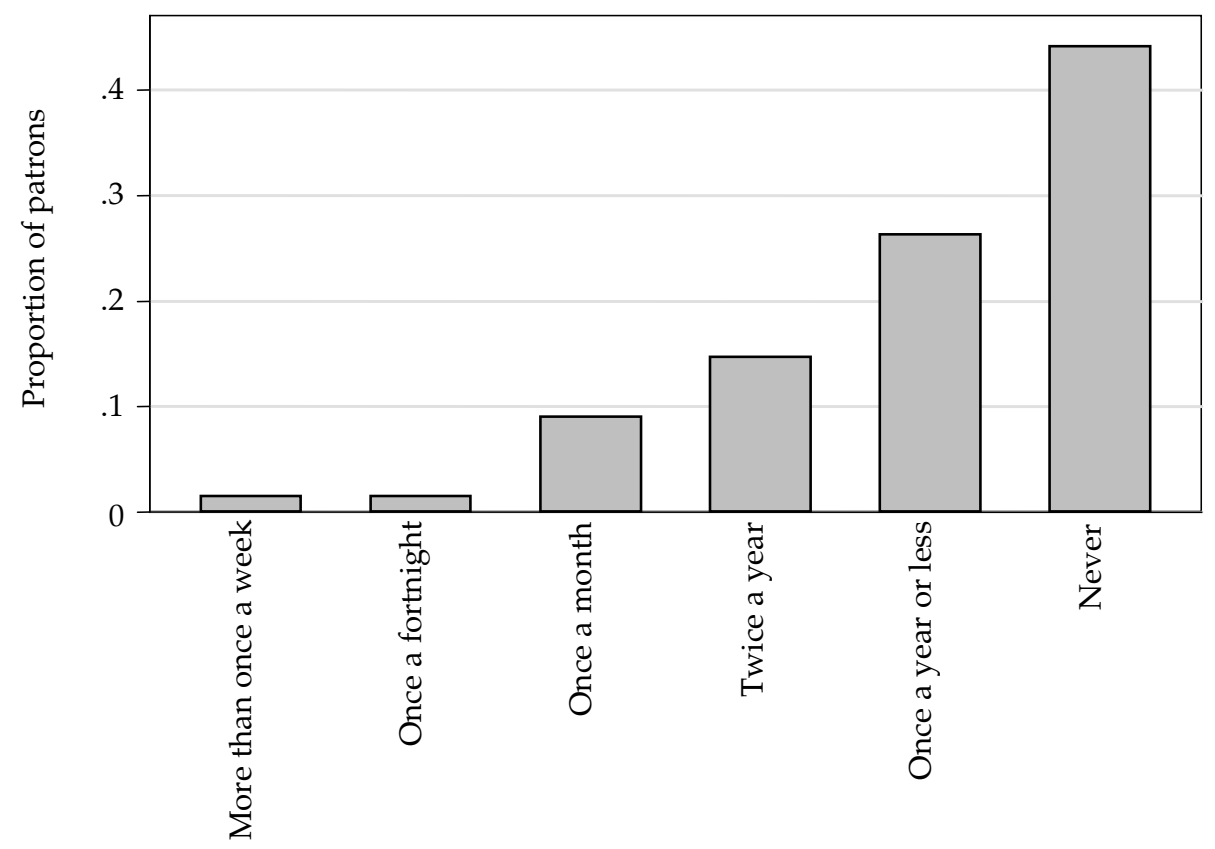

Figure 2: Frequency of meeting patrons: Other major categories

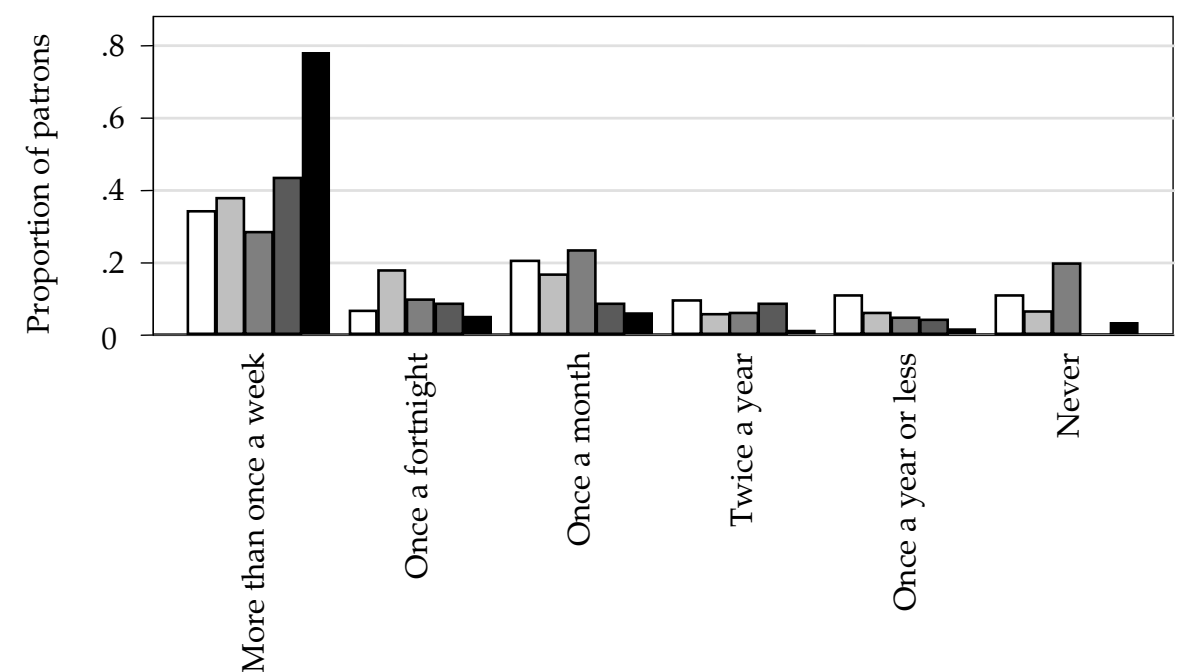

Landlords

Local officials

Tehsil-provincial officials 
Figure 3: Ability to contact patrons: Politicians

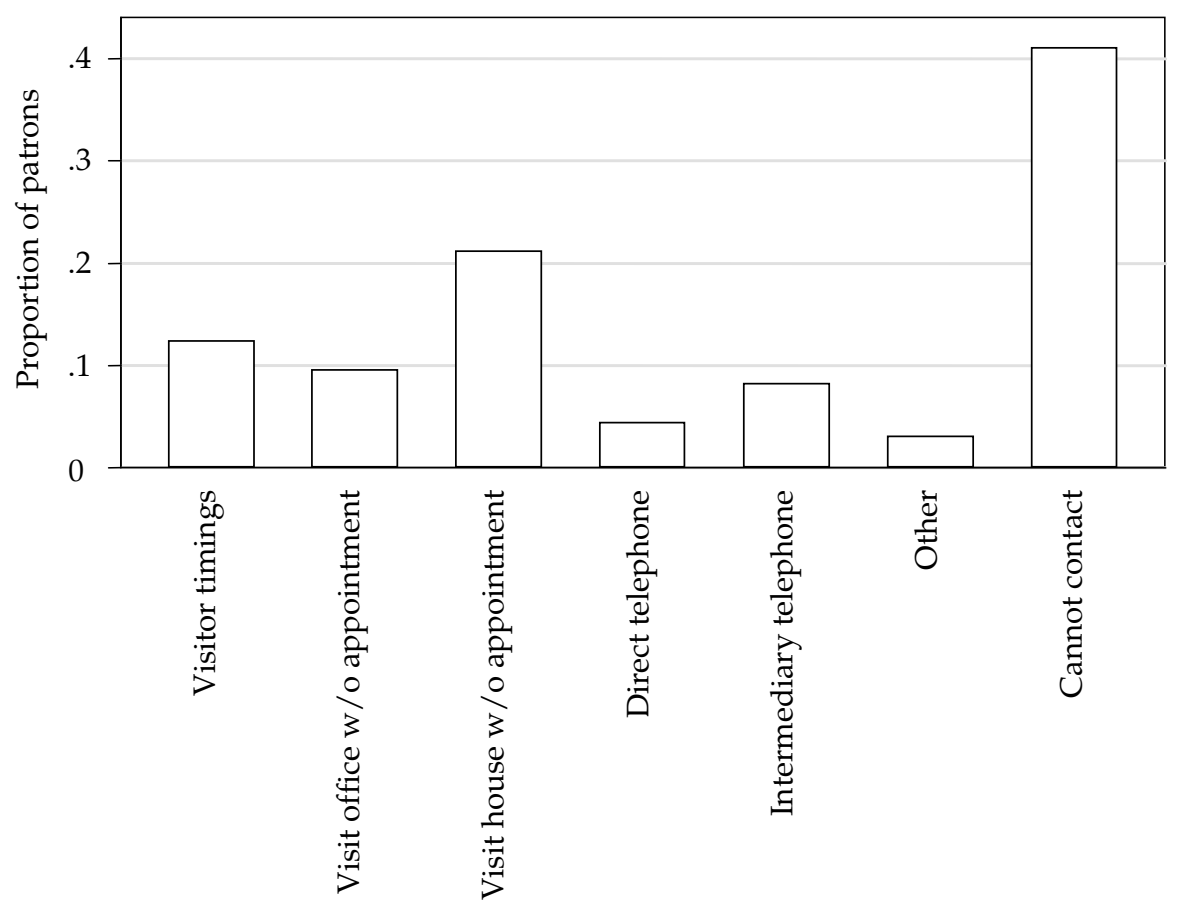

Figure 4: Ability to contact patrons: Other major categories

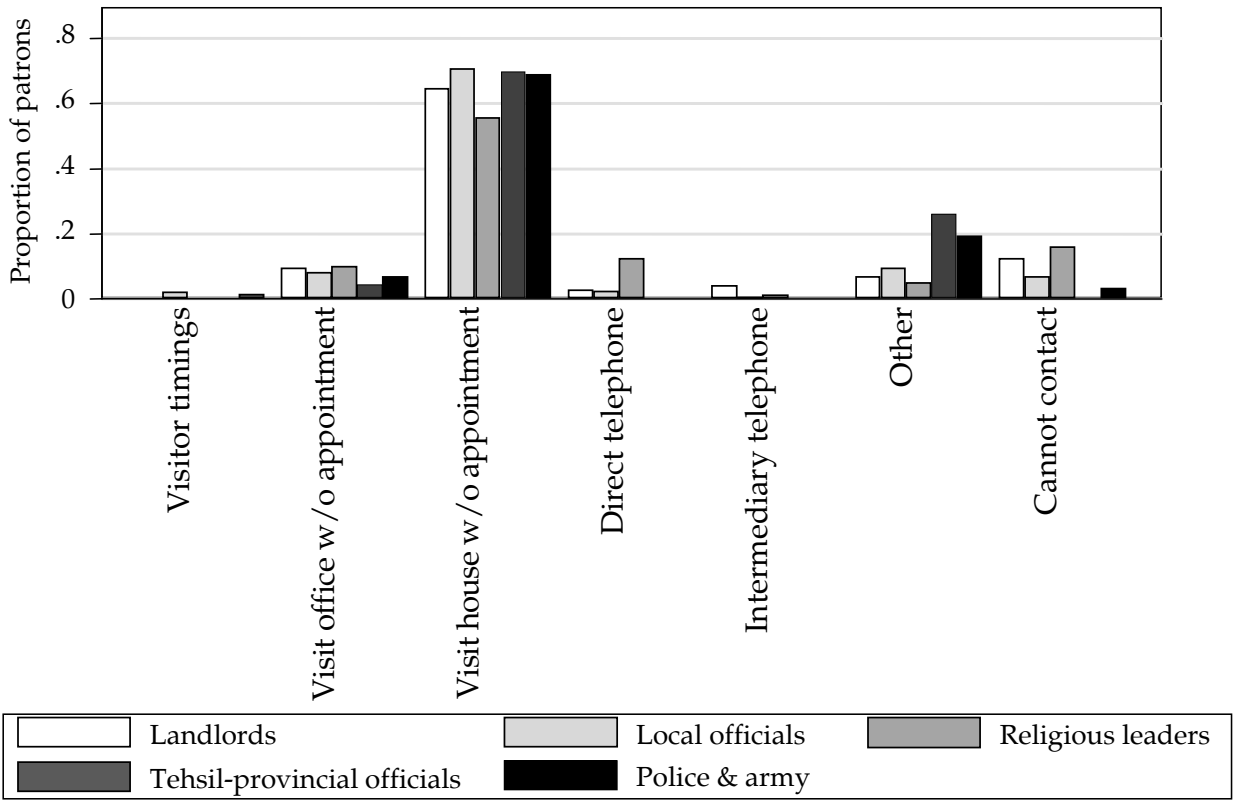


Mohmand and Gazdar (2007) discuss how "biraderi" or clans in Punjab are kinship groups based on lineage and how these biraderis can be ranked in terms of socioeconomic importance within rural communities. Thus, relationships within and across biraderis are important determinants of the position in the socioeconomic hierarchy, and these relationships have been reinforced over time. However, Mohmand and Gazdar (2007) and Cheema (2007) discuss certain factors that have reduced the central role of biraderi in rural patron-client relations, such as (i) the local population's reduced dependence on land, (ii) increased availability of nonfarm labor opportunities, and (iii) party-based political processes.

As Figure 5 shows, the majority of individuals that households named in each of our patron categories belong to a different biraderi from that of the household. However, this varies substantially between the different categories. Individuals in positions that might involve broadbased interaction, such as religious leaders, large local landlords, and politicians, were most likely to be named by households of a different biraderi than their own. Forthcoming work examines patterns of assistance and government services delivery by biraderi affiliation.

Figure 5: Patron and client biraderi

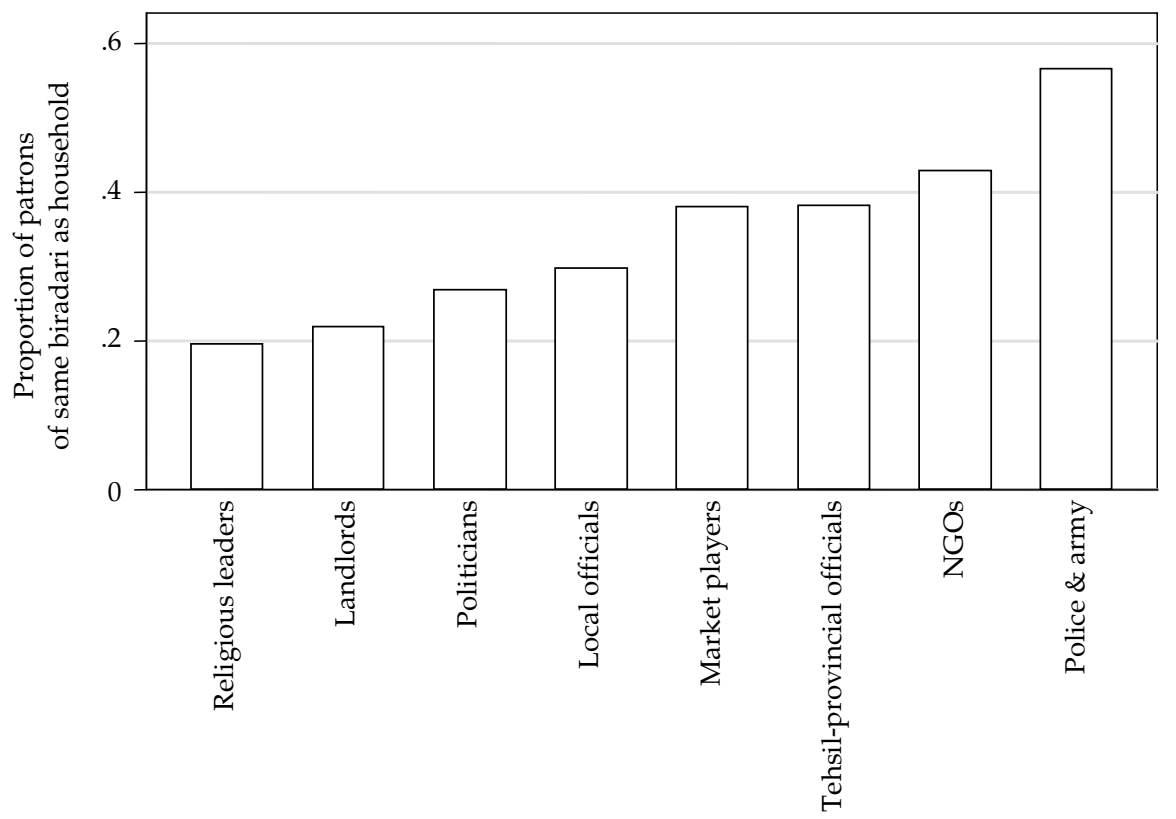




\section{Assistance from Patrons to Households}

A quarter of the households surveyed reported receiving assistance in at least one of the areas identified in the questionnaire. Figures 6-7 show the number of areas in which households reported receiving assistance from a single patron or from any patron. Most households did not report receiving assistance in any of the areas identified in the survey, but a small percentage of those who did, reported receiving assistance in several areas.

Figure 6: Households that reported receiving assistance from a single patron

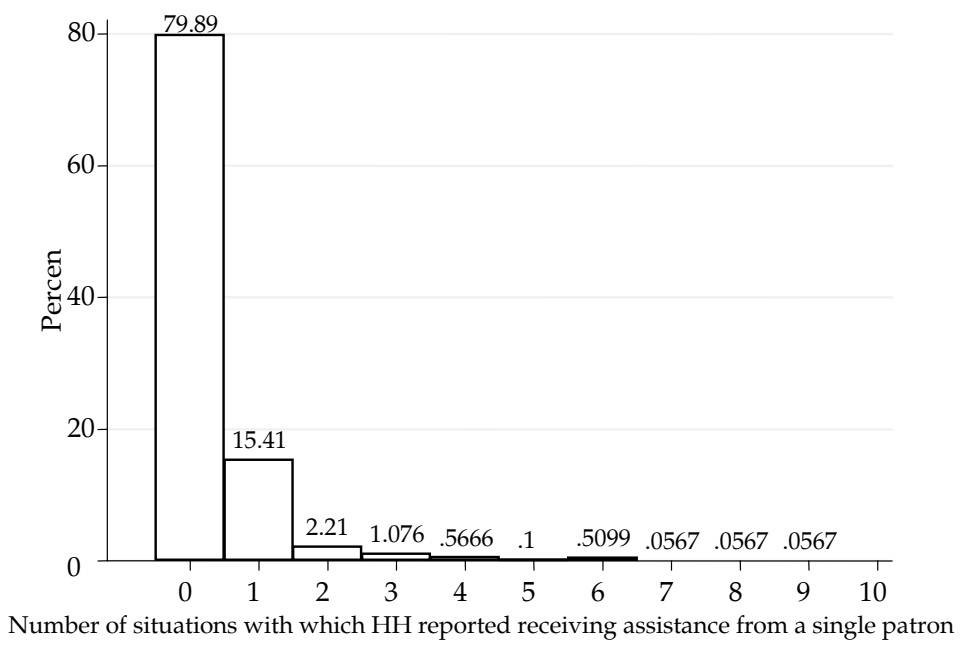

Figure 7: Households that reported receiving assistance from any patron

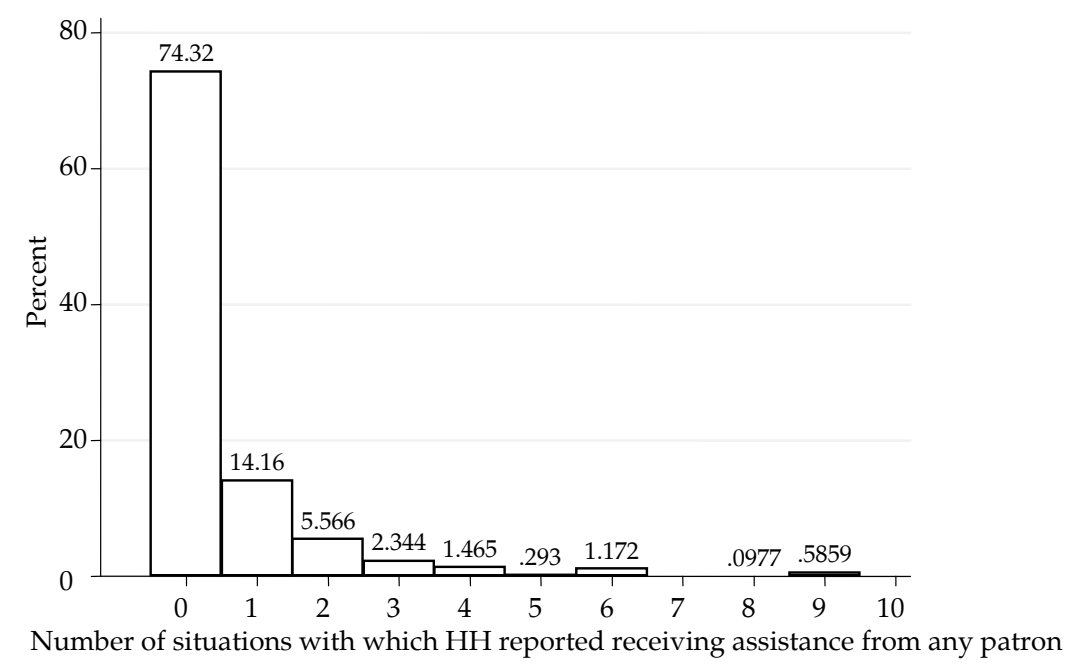


As shown in Figure 8, by far the most common area in which households receive assistance is in applying for a national identity card. This card is required for many private and public functions, such as opening a bank account or receiving certain government safety net program benefits, but it is also required to vote. This could be consistent with patrons assisting clients purely as a service to them or as part of preelection campaigning. ${ }^{3}$

Figure 8: Patron assistance to clients

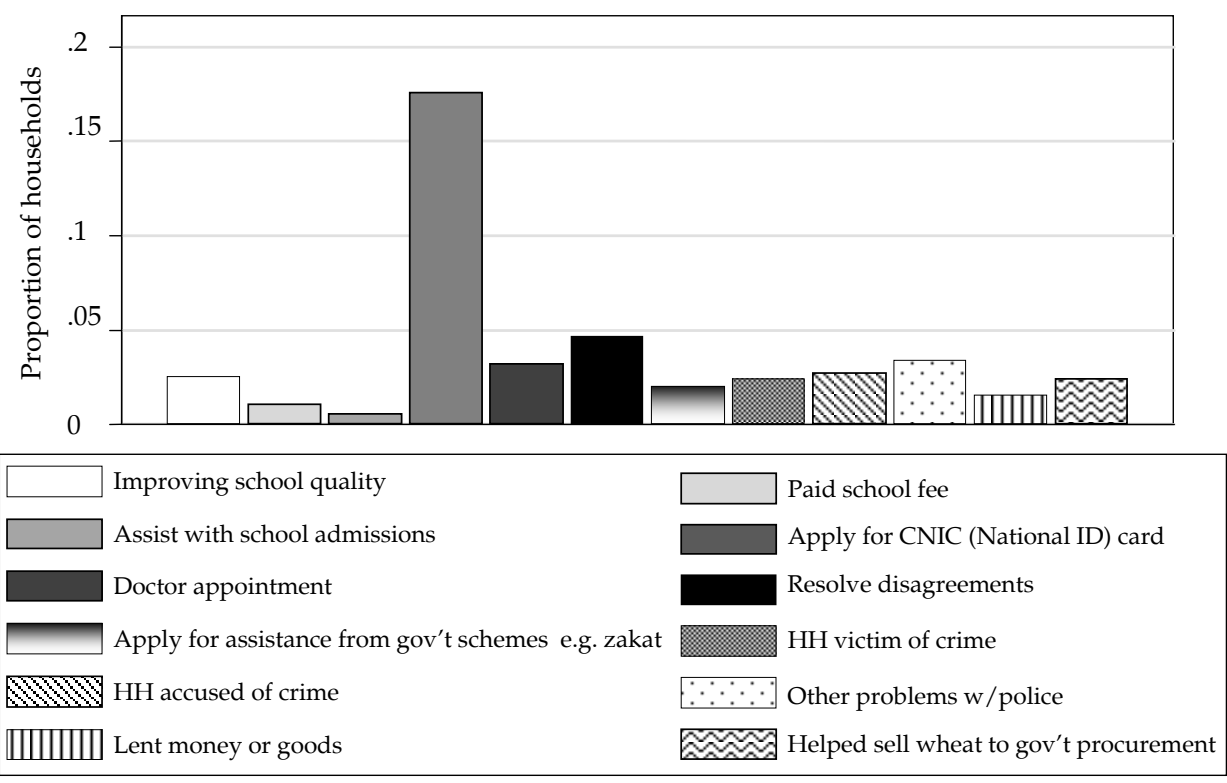

One of the major questions raised by the issue of patronage is whether these vertical social networks tend to assist households in needfor example, by helping them bypass poorly functioning public service delivery mechanisms - or if they privilege those who are both better resourced and better connected, leaving out the vulnerable. Simply because vulnerable households are likely to need more assistance, we would expect the measures of assistance to be biased toward these households, even if all households have equal opportunities to access patron assistance. However, the descriptive regressions in Table 3 suggest the opposite: households likely to be vulnerable, such as landless and female-headed households, appear less likely to receive assistance from patrons, suggesting that patronage activity might increase inequality of outcomes.

3 The data were collected midway between elections, so this might be expected to increase dramatically in the run-up to an election. 
As the results show, the landless have a lower chance of receiving assistance from a patron while female-headed households have the same chance of receiving assistance as other households. So the evidence implies that vulnerable households are less likely to receive assistance from patrons, suggesting that patronage activity could increase inequality of outcomes.

The majority of households did not report receiving assistance from the patron with whom they were connected. However, this does not reveal whether they simply did not need assistance in any of these areas, or rather were unable to activate it. This is sometimes addressed in surveys in one of two ways:

1. Asking hypothetical questions such as "who/how many people could you rely on to help if...?" This is often used in studies on social networks (e.g., Caeyers \& Dercon, 2008). It raises a number of respondent bias issues. For example, when households have dealt with recent shocks and challenges, they may have in mind more (or potentially fewer) people they can reliably call on for assistance.

2. Asking whether assistance was sought unsuccessfully. This has the major disadvantage of excluding respondents who decided not to seek assistance because they anticipated they would be unsuccessful.

Instead, we asked questions aimed at comparing relatively objective measures of need with whether the household received assistance. These include household characteristics that can proxy for advantage or disadvantage, such as the value of the physical property or whether the household is female-headed, etc. However, the survey also included questions that could match specific needs with assistance in specific areas. For example, in the case of medical attention, one module of the survey asked households about their illnesses and visits to the doctor. This can be matched with responses to questions on whether patrons assisted the household secure an appointment with a doctor. The results from these matched questions will be analyzed in future work.

The questions about all areas of need preceded and were separate from the module on patron assistance in order to reduce potential bias in the answers from other questions about patron activity. 
Table 3: Correlates of assistance from patrons

\begin{tabular}{|c|c|c|c|c|c|c|c|c|}
\hline & (1) & (2) & (3) & (4) & (5) & (6) & (7) & (8) \\
\hline & \multicolumn{8}{|c|}{ LPM: Household reports receiving assistance from one or more of the following individuals: } \\
\hline & $\begin{array}{c}\text { Landlords } \\
\text { owning > } \\
50 \text { acres }\end{array}$ & Politicians & $\begin{array}{c}\text { Local } \\
\text { officials }\end{array}$ & $\begin{array}{c}\text { Tehsil, } \\
\text { district, or } \\
\text { provincial } \\
\text { officials }\end{array}$ & $\begin{array}{l}\text { Police or } \\
\text { army } \\
\text { personnel }\end{array}$ & $\begin{array}{l}\text { Religious } \\
\text { leaders }\end{array}$ & $\begin{array}{l}\text { Market } \\
\text { players }\end{array}$ & NGOs \\
\hline \multicolumn{9}{|l|}{ VARIABLES } \\
\hline \multirow[t]{2}{*}{ Owns dwelling } & 0.00784 & 0.0167 & 0.0531 & $0.0186^{*}$ & $0.00493^{* *}$ & 0.00562 & -0.0107 & 0.00398 \\
\hline & $(0.0167)$ & $(0.0143)$ & $(0.0343)$ & $(0.00926)$ & $(0.00192)$ & $(0.0132)$ & $(0.00729)$ & $(0.00256)$ \\
\hline \multirow[t]{2}{*}{ Owns agricultural land } & 0.0160 & 0.0485 & 0.0166 & $0.0163^{* *}$ & 0.00882 & $0.0215^{* *}$ & $0.0224^{*}$ & -0.00154 \\
\hline & $(0.0205)$ & $(0.0295)$ & $(0.0127)$ & $(0.00564)$ & $(0.00749)$ & $(0.00743)$ & $(0.0123)$ & $(0.00124)$ \\
\hline \multirow[t]{2}{*}{ Female-headed } & $-0.0410^{* *}$ & -0.0205 & -0.0106 & -0.00166 & $-0.00947^{*}$ & $-0.0342^{* * *}$ & 0.00808 & -0.00227 \\
\hline & $(0.0137)$ & $(0.0282)$ & $(0.0573)$ & $(0.0198)$ & $(0.00493)$ & $(0.00753)$ & $(0.0122)$ & $(0.00241)$ \\
\hline \multirow[t]{2}{*}{ Northern Punjab } & -0.0239 & $0.0839^{*}$ & -0.0472 & $-0.0363^{* *}$ & -0.00459 & $-0.0326^{* * *}$ & 0.0373 & 0.0112 \\
\hline & $(0.0210)$ & $(0.0385)$ & $(0.0642)$ & $(0.0139)$ & $(0.00789)$ & $(0.00723)$ & $(0.0252)$ & $(0.00641)$ \\
\hline \multirow[t]{2}{*}{ Southern Punjab } & -0.0132 & -0.00576 & -0.0506 & $-0.0378^{* *}$ & -0.0111 & $-0.0263^{* *}$ & 0.00398 & 0.000194 \\
\hline & $(0.0249)$ & $(0.0203)$ & $(0.0380)$ & $(0.0130)$ & $(0.00651)$ & $(0.00881)$ & $(0.00257)$ & $(0.000251)$ \\
\hline \multirow[t]{2}{*}{ Constant } & $0.0358^{* *}$ & 0.00441 & $0.122^{* * *}$ & $0.0225^{* *}$ & 0.00511 & $0.0325^{* *}$ & -0.000458 & -0.00250 \\
\hline & $(0.0152)$ & $(0.0204)$ & $(0.0287)$ & $(0.00934)$ & $(0.00496)$ & $(0.0118)$ & $(0.00891)$ & $(0.00154)$ \\
\hline Observations & 1,012 & 1,012 & 1,012 & 1,012 & 1,012 & 1,012 & 1,012 & 1,012 \\
\hline R-squared & 0.008 & 0.044 & 0.011 & 0.024 & 0.008 & 0.016 & 0.035 & 0.009 \\
\hline
\end{tabular}

Notes: Cluster-robust standard errors (clustered at national assembly constituency level) in parentheses. Regressions are for any assistance from a patron (i.e., not conditional on knowing the patron). ${ }^{* *}=\mathrm{p}<0.01,{ }^{* *}=\mathrm{p}<0.05{ }^{*}=\mathrm{p}<0.1$. 


\section{Assistance from Clients to Patrons}

Following the discussions in Platteau (1990) and Scott (1972) cited above, we also examine how patrons might seek assistance from their clients. Respondents were asked about a range of unpaid services they might have performed for each patron. As Figure 9 shows, by far the most common area of assistance-with about 30 percent of households assisting at least one patron-was that of events, such as weddings, funerals, or religious festivals. The second most common was political activity. Unpaid agricultural and construction labor were uncommon. As shown in Table 4, it is actually the better-off households who appear to assist patrons, i.e., those households that own their own home and land.

Figure 9: Client assistance to patrons

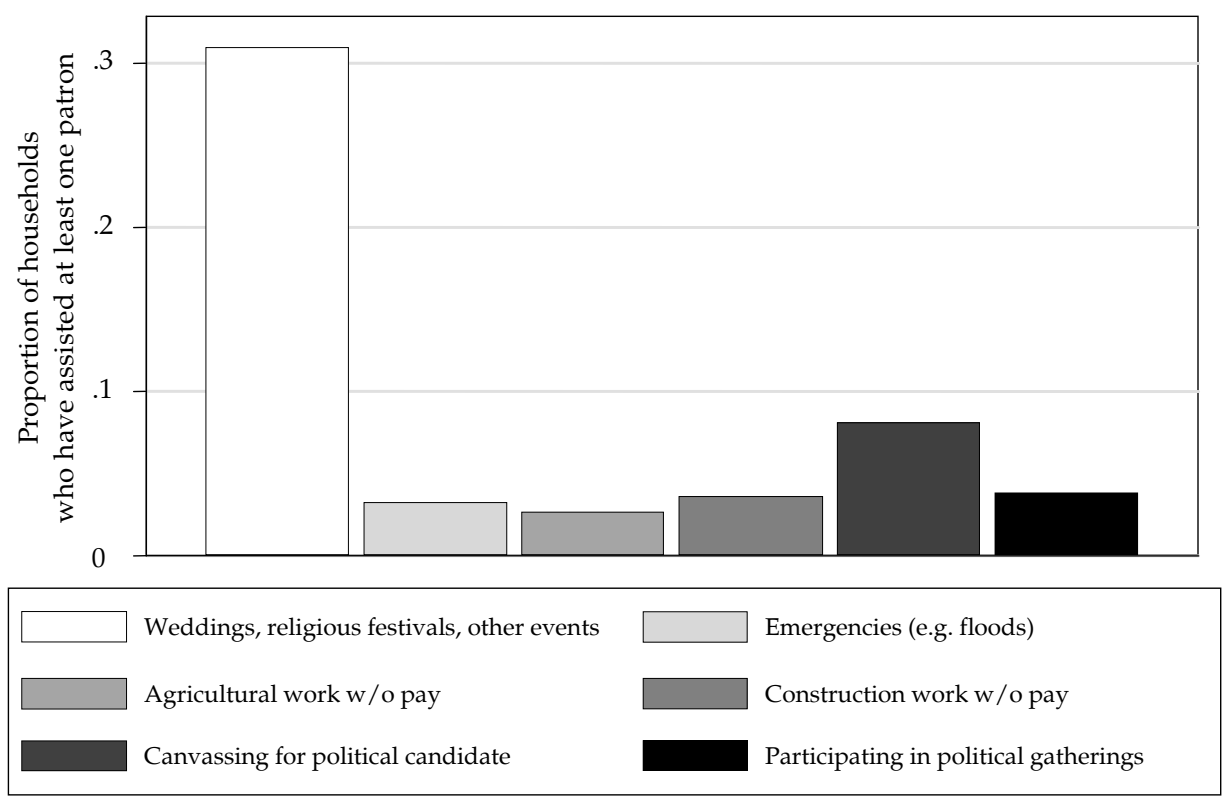


Table 4: Households' assistance to patrons

\begin{tabular}{|c|c|c|c|c|c|c|c|c|}
\hline & (1) & $(2)$ & (3) & (4) & (5) & (6) & (7) & (8) \\
\hline & \multicolumn{8}{|c|}{ LPM: Household reports assisting patron in one or more areas: } \\
\hline & $\begin{array}{c}\text { Landlords } \\
\text { owning > } \\
50 \text { acres }\end{array}$ & Politicians & $\begin{array}{c}\text { Local } \\
\text { officials }\end{array}$ & $\begin{array}{l}\text { Tehsil, } \\
\text { district, or } \\
\text { provincial } \\
\text { officials }\end{array}$ & $\begin{array}{c}\text { Police } \\
\text { and army } \\
\text { personnel }\end{array}$ & $\begin{array}{c}\text { Religious } \\
\text { leaders }\end{array}$ & $\begin{array}{l}\text { Market } \\
\text { players }\end{array}$ & NGOs \\
\hline \multicolumn{9}{|l|}{ VARIABLES } \\
\hline \multirow[t]{2}{*}{ Owns dwelling } & 0.0107 & $0.0319^{* *}$ & $0.112^{* *}$ & $0.0179^{*}$ & 0.00222 & $0.135^{* *}$ & -0.00618 & $0.00673^{*}$ \\
\hline & $(0.0162)$ & $(0.0105)$ & $(0.0433)$ & $(0.00861)$ & $(0.00188)$ & $(0.0520)$ & $(0.00615)$ & $(0.00321)$ \\
\hline \multirow[t]{2}{*}{ Owns agricultural land } & $0.0283^{*}$ & $0.0633^{*}$ & -0.000256 & 0.0123 & -0.00164 & -0.0278 & 0.00214 & 0.00183 \\
\hline & $(0.0143)$ & $(0.0333)$ & $(0.0312)$ & $(0.0145)$ & $(0.00143)$ & $(0.0172)$ & $(0.00328)$ & $(0.00589)$ \\
\hline \multirow[t]{2}{*}{ Female-headed } & $-0.0434^{* *}$ & -0.00893 & 0.0705 & 0.0257 & 0.0150 & -0.0721 & 0.0104 & $-0.00599^{*}$ \\
\hline & $(0.0168)$ & $(0.0213)$ & $(0.0651)$ & $(0.0275)$ & $(0.0152)$ & $(0.0476)$ & $(0.0123)$ & $(0.00319)$ \\
\hline \multirow[t]{2}{*}{ Northern Punjab } & $-0.0544^{* *}$ & 0.0141 & -0.104 & $-0.0430^{*}$ & 0.000962 & -0.178 & -0.000513 & 0.00645 \\
\hline & $(0.0235)$ & $(0.0501)$ & $(0.0612)$ & $(0.0205)$ & $(0.00107)$ & $(0.117)$ & $(0.00444)$ & $(0.00735)$ \\
\hline \multirow[t]{2}{*}{ Southern Punjab } & -0.0335 & -0.0362 & -0.0349 & -0.0345 & 0.00441 & -0.111 & 0.00190 & -0.000996 \\
\hline & $(0.0227)$ & $(0.0335)$ & $(0.0813)$ & $(0.0204)$ & $(0.00314)$ & $(0.0841)$ & $(0.00534)$ & $(0.00508)$ \\
\hline \multirow[t]{2}{*}{ Constant } & $0.0405^{* *}$ & 0.0219 & $0.107^{* *}$ & 0.0263 & -0.00284 & $0.181^{* *}$ & 0.00789 & -0.00106 \\
\hline & $(0.0153)$ & $(0.0234)$ & $(0.0364)$ & $(0.0152)$ & $(0.00262)$ & $(0.0799)$ & $(0.00617)$ & $(0.00266)$ \\
\hline Observations & 1,012 & 1,012 & 1,012 & 1,012 & 1,012 & 1,012 & 1,012 & 1,012 \\
\hline R-squared & 0.027 & 0.031 & 0.032 & 0.024 & 0.018 & 0.058 & 0.003 & 0.004 \\
\hline
\end{tabular}

Note: Cluster-robust standard errors (clustered at national assembly constituency level) in parentheses. ${ }^{* *}=\mathrm{p}<0.01,{ }^{* *}=\mathrm{p}<0.05,{ }^{*}=\mathrm{p}<0.1$. 


\section{Patronage and Politics}

One way that the literature suggests clients may be expected to reciprocate could be for them to vote for particular patrons or candidates endorsed by patrons, who in turn deliver state services to the patrons individually as well as to their communities. Figures 10-11 break down which patrons recommended that a household vote for a specific candidate in the last election (2008). Very large proportions (40 to 50 percent) of local and higher-level officials and landlords recommended candidates; of the local government officials, the local numberdar is the most likely to have recommended a candidate (not shown). Religious leaders appear to be the least involved in direct endorsement of political candidates.

These results are consistent with clientelist campaigning through local leaders, and with the bloc voting activities observed in qualitative work on rural Punjab, where local leaders determine the candidate choice for an entire group of people, e.g., by biraderi. This evidence suggests that households may not feel their vote choice is secret enough to deviate from the candidate chosen for their bloc. Future work will include formal modeling of the bloc voting process and relationship between politicians and local influentials.

Figure 10: Patron recommendations for clients' votes

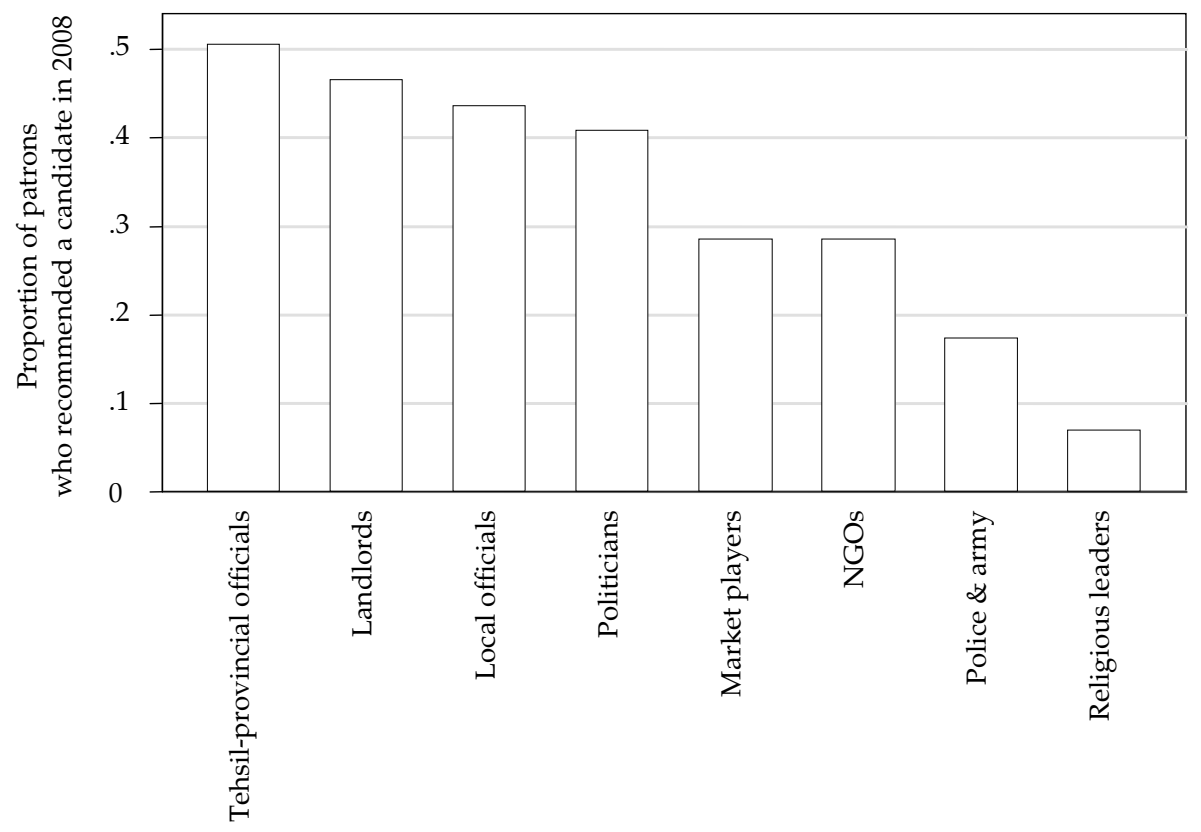


Figure 11: Patron knowledge of clients' votes

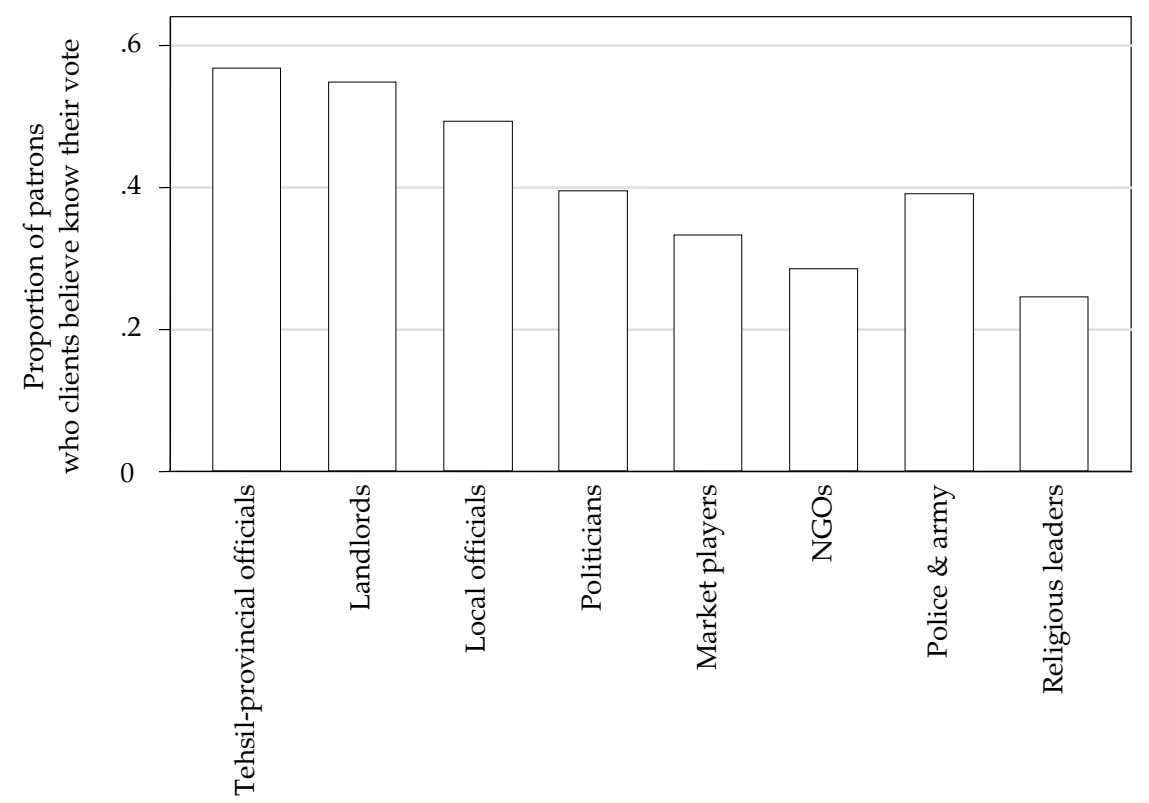

\section{Conclusions}

The intervention of local elites is frequently cited as an impediment to development policy implementation in many countries. In a descriptive analysis of an original household dataset from rural Punjab, we have found that:

1. Households report connections with a range of officials and interact most commonly with local officials. A large number of households also report interacting with their provincial and national politicians.

2. Many households report receiving active assistance both from local officials and provincial and national politicians in accessing certain state services, particularly in applying for national identity cards.

3. Households report links with many patrons outside their own biraderi or clan.

4. Vulnerable households, such as landless and female-headed households, appear less likely to interact with and less likely to receive assistance from patrons, suggesting that patronage activity could increase inequality of outcomes.

5. Better-off households appear more likely to assist patrons in a range of areas. 
6. Local officials and politicians tended to recommend candidates in the last election and rural households were strongly convinced that their vote was not secret from the patrons or officials; this is possibly consistent with patronage-based politics and bloc voting.

Future work will include formal modeling and econometric testing of the underlying factors that strengthen or weaken the influence of the patron-client relationship and the delivery of particular state-provided goods and services. 


\section{References}

Arif, G. M. (2006). Targeting efficiency of poverty reduction programs in Pakistan (Working Paper No. 4). Islamabad: Asian Development Bank, Pakistan Resident Mission.

Banerjee, A., Duflo, E., \& Qian, N. (2009). On the road: Access to transportation infrastructure and economic growth in China (Mimeo, Institutions and Governance Program). Berkeley, CA: University of California, Berkeley.

Bardhan, P., \& Mookherjee, D. (2006). Pro-poor targeting and accountability of local governments in West Bengal. Journal of Development Economics, 79, 303-327.

Brusco, V., Nazareno, M., \& Stokes, S. C. (2002, March). Clientelism and democracy: Evidence from Argentina. Paper presented at the Conference on Political Parties and Legislative Organization in Parliamentary and Presidential Regimes, Yale University, New Haven, CT.

Caeyers, B., \& Dercon, S. (2008). Political connections and social networks in targeted transfer programs: Evidence from rural Ethiopia (Working Paper No. 2008-33). Oxford, UK: University of Oxford, Centre for the Study of African Economies.

Cheema, A. (2007). Governance impediments to pro-poor change in Pakistan (Thematic paper for TA4319: Determinants and Drivers of Poverty Reduction and ADB's Contribution in Rural Pakistan). Islamabad, Pakistan: Asian Development Bank.

Cheema, A., Mohmand, S. K., \& Patnam, M. (2009). Colonial proprietary elites and institutions: The persistence of de facto political dominance (Mimeo). Lahore, Pakistan: Lahore University of Management Sciences.

Fafchamps, M. (2008). Risk sharing between households. In J. Benhabib, A. Bisin, \& M. O. Jackson (Eds.), Handbook of social economics (vol. 1A). Amsterdam, The Netherlands: Elsevier Science.

Fafchamps, M., \& Labonne, J. (2012). Nepotism and punishment: The (mis-) performance of elected local officials in the Philippines. Unpublished manuscript, Oxford University, UK. 
Keefer, P., \& Khemani, S. (2009). When do legislators pass on "pork"? The determinants of legislator utilization of a constituency development fund in India (Policy Research Working Paper No. 4929). Washington, DC: World Bank.

Keefer, P., \& Vlaicu, R. (2005). Democracy, credibility and clientelism (Policy Research Working Paper No. 3472). Washington, DC: World Bank.

Khan, M., \& Jomo, K. S. (2000). Rents, rent-seeking and economic development: Theory and evidence in Asia. Cambridge, UK: Cambridge University Press.

Labonne, J. (2012). The local electoral impacts of conditional cash transfers: Evidence from a field experiment (Working Paper No. WPS/2012-09). Oxford, UK: Centre for the Study of African Economies.

Lyon, S. M. (2004). An anthropological analysis of local politics and patronage in a Pakistani village. Lampeter, UK: Edwin Mellen Press.

Mansuri, G., \& Rao, V. (2004). Community-based (and driven) development: A critical review (Policy Research Working Paper No. 3209). Washington, DC: World Bank.

Martin, N. (in press). Politics, patronage and debt-bondage in the Pakistani Punjab. London, UK: Berghahn \& Social Science Press.

Mohmand, S. K., \& Gazdar, H. (2007). Social structures in rural Punjab (Thematic paper for TA4319: Determinants and Drivers of Poverty Reduction and ADB's Contribution in Rural Pakistan). Islamabad, Pakistan: Asian Development Bank.

Pan, L., \& Christiaensen, L. (2011). Who is vouching for the input voucher? Decentralized targeting and elite capture in Tanzania (Policy Research Working Paper No. 5651). Washington, DC: World Bank.

Platteau, J.-P. (1995a). A framework for the analysis of evolving patron-client ties in agrarian economies. World Development, 23(5), 767-786.

Platteau, J.-P. (1995b). An Indian model of aristocratic patronage. Oxford Economic Papers, 47(4), 636-662.

Robinson, J. A., \& Verdier, T. (2001). The political economy of clientelism. Unpublished manuscript. 
Scott, J. (1972). Patron-client politics and political change in Southeast Asia. American Political Science Review, 66(1), 91-113.

Shami, M. (2010a). Collective action, clientelism and connectivity (Working Paper No. 2010/14). Denmark: University of Copenhagen: Institute of Food and Resource Economics.

Shami, M. (2010b). The impact of market exposure on public goods provision (Working Paper No. 2010/13). Denmark: University of Copenhagen, Institute of Food and Resource Economics.

Udry, C. (1996). Gender, agricultural production, and the theory of the household. Journal of Political Economy, 104(5), 1010-1046.

Wantchekon, L. (2002). Clientelism and voting behavior: Evidence from a field experiment in Benin (Working Paper). New York, NY: New York University. 